\title{
Doing More with Less: Civic Practices for Longer-Term Impact in Global Service-Learning
}

\author{
Nuria Alonso García \\ Nicholas V. Longo
}

Providence College

\begin{abstract}
:
This essay explores the potential value of short-term study abroad experiences within the unique framework of a new global service-learning program at Providence College which connects international with local engagement as a way to "do more with less." The authors first introduce a typology for global service-learning, illustrating how this model fits within current approaches to international service-learning. They then describe a case study, Voices Across Borders, the global service-learning program which provides opportunities for students to engage with rural Nicaraguan and urban Providence youth through projects that harness the power of storytelling to make connections across borders. Based on the lessons from this effort, the essay offers a set of civic practices that can support the longer-term impact of short-term global service-learning, including i) fostering storytelling across borders; ii) cultivating students as partners; iii) developing reciprocal community partnerships; and iv) creating public work, visual, auditory or performing public artifacts. After describing the challenges for short-term international engagement, the authors conclude that global service-learning initiatives might more appropriately be focused on collaborative learning, rather than service, as a way of thinking more comprehensively about the entire global "ecology of education" which links learning at the international and local levels.
\end{abstract}

\section{Introduction}

Over the past decade, campuses have responded to the interest among students in short-term study abroad trips by creating more opportunities for international experiences outside the semester (or year) abroad, as these shorter trips have now grown to become a majority of student international experiences. According to the Institute for International Education Open Doors Report (2015), in 2013-14, the number of U.S. undergraduate students who studied abroad that participated in short-term programs (summer, or eight weeks or less) grew to $62.1 \%$--a dramatic rise from only 3\% in 1996-97 (Donnelly-Smith, 2009).

Yet, the duration of these programs also presents a potential challenge for educators interested in maximizing the cultural, linguistic, and civic impact of international immersion. The conventional wisdom derived from the relativist paradigm (Vande Berg, Paige, \& Lou, 2012) - that encourages students to live with native families, to enroll directly in host university courses, and to study abroad for longer-has been that "more is better" (Dwyer, 2004). However, recent research demonstrates that while program duration correlates to students' development of intercultural competency (Engle 
\& Engle, 2012) and semester-long programs offer greater opportunities for cultural engagement, the length of the study abroad experience does not impact intercultural development as dramatically as traditionally assumed. Aligned with these research insights, many international educators are rightly asking some version of the question: Can short-term trips have the transformational impact intended for longer study abroad experiences?

We aim to address this question by presenting the unique framework of a new short-term Global Service Learning Program at Providence College that has taken this challenge seriously by reframing the immersion experiences as "global" and part of a broader ecology of learning. After all, as Reilly \& Senders (2009) note in questioning the usefulness of the term "abroad" in an interdependent world, "our responsibilities are truly global" (p. 262). Thus, when short-term international service-learning is integrated with local immersion and engagement in our globalized local communities, new possibilities for transformation emerge. In our case study this has meant engaging learners in international service experiences in Latin America that have meaningful connections with the transnational communities in Providence, Rhode Island for the past five years, and in so doing learners are becoming more self-reflective, culturally self-aware and more conscious of their position in the world and of their social responsibility.

This essay first introduces a typology for understanding how this model of global servicelearning fits within current approaches to international service-learning. We then describe the global service-learning program in El Manzano Uno, Nicaragua and Providence, along with a set of civic practices that nurture international and local community engagement as part of a service-learning continuum. The essay concludes by examining the challenges encountered in developing and sustaining partnerships, engaging students, and ensuring the longer-lasting impact of the international service-learning experience. We have come to realize that, ultimately, it may be that these trips are more about learning than service which we see as a more appropriate emphasis for any kind of short-term international engagement including service-learning trips.

\section{Typology of global service-learning}

The growth of short-term study abroad should be seen as a welcome trend from an educational perspective. It allows more students to have an international experience, overcoming financial and other constraints that arise from a semester or year abroad commitment. It often introduces students to a target language and diverse cultures, leads to further explorations of global issues and travel, and is also more likely to be integrated into home school curricula (Vande Berg, Paige, \& Lou, 2012). Global service-learning is a significant and growing area within the short-term study abroad experiences (Bringle, Hatcher \& Jones, 2011). As two of the leading proponents of the field, Eric Hartman and Richard Kiely (2014) explain, global service-learning is distinctive in the study abroad experience in that: it is committed to intercultural competence development; it has a focus on structural analysis tied to consideration of power, privilege, and hegemonic assumptions; it takes place within a global marketization of volunteerism; it is typically immersive; and it engages the critical global civic and moral imagination (p. 56).

The umbrella of "global service learning," however, includes varying approaches. At Providence College alone we offer at least four different models for global service-learning, not to 
mention other short-term abroad travel courses and co-curricular experiences such as international study trips, musical and athletic performances, and study away courses. The global service-learning options outlined below (and in Chart 1) offer important features for understanding the distinctive yet overlapping models for global service-learning.

\section{Chart 1.1}

\begin{tabular}{|c|c|c|c|}
\hline Type & Description & Benefits & Challenges \\
\hline $\begin{array}{l}\text { Co-Curricular } \\
\text { International Service } \\
\text { Trip }\end{array}$ & $\begin{array}{l}\text { short-term, non credit } \\
\text { bearing international } \\
\text { service trip }\end{array}$ & $\begin{array}{l}\text { i) aligns well with } \\
\text { students' schedules } \\
\text { ii) high levels of student } \\
\text { leadership }\end{array}$ & $\begin{array}{l}\text { i) does not allow for } \\
\text { adequate preparation or } \\
\text { follow-up } \\
\text { ii) risk of community } \\
\text { exploitation }\end{array}$ \\
\hline $\begin{array}{l}\text { Short-Term International } \\
\text { Service-Learning Course }\end{array}$ & $\begin{array}{l}\text { faculty led short-term, } \\
\text { credit bearing } \\
\text { international service- } \\
\text { learning trip }\end{array}$ & $\begin{array}{l}\text { i) allows for deeper } \\
\text { international partnerships } \\
\text { ii) focuses intentionally } \\
\text { on student learning }\end{array}$ & $\begin{array}{l}\text { i) no opportunity for local } \\
\text { engagement or rigorous } \\
\text { follow-up }\end{array}$ \\
\hline $\begin{array}{l}\text { Course Embedded Spring } \\
\text { Break International } \\
\text { Service Trip }\end{array}$ & $\begin{array}{l}\text { global service-learning } \\
\text { semester-long course } \\
\text { with curriculum post- } \\
\text { trip, co-developed by } \\
\text { faculty and students }\end{array}$ & $\begin{array}{l}\text { i) allows time to prepare } \\
\text { together as a class prior } \\
\text { to the immersion } \\
\text { ii) allows to build upon } \\
\text { international service with } \\
\text { follow-up through } \\
\text { reflection, along with } \\
\text { local community } \\
\text { engagement }\end{array}$ & $\begin{array}{l}\text { i) time-bound to one week } \\
\text { of international immersion } \\
\text { ii) little time for } \\
\text { international immersion }\end{array}$ \\
\hline $\begin{array}{l}\text { Curricular Embedded } \\
\text { Pre-or Post Course } \\
\text { International Service } \\
\text { Trip }\end{array}$ & $\begin{array}{l}\text { global service-learning } \\
\text { semester-long course } \\
\text { with international } \\
\text { immersion prior to or } \\
\text { post course during } \\
\text { winter or summer }\end{array}$ & $\begin{array}{l}\text { i) allows for longer-time } \\
\text { periods abroad } \\
\text { ii) allows for the } \\
\text { experience to either } \\
\text { frame the learning or } \\
\text { serve as culmination }\end{array}$ & $\begin{array}{l}\text { i) less time to prepare for } \\
\text { the time abroad, if } \\
\text { international immersion } \\
\text { precedes, or little time for } \\
\text { follow-up }\end{array}$ \\
\hline
\end{tabular}

\section{Co-curricular international service trip}

Perhaps the most accessible and common global service-learning experience is a short-term, non-credit bearing international service trip. These trips are often held during spring break but also during winter and summer breaks. At Providence College these trips are offered through the Campus Ministry and initially through the Feinstein Institute for Public Service to locations such as Guatemala, Haiti, Jamaica, Dominican Republic, and Peru. The advantage of this model is that it is the most accessible for students' schedules and often fosters (and requires) high levels of student leadership. And yet, co-curricular service trips do not allow for adequate preparation prior to the immersion experience or post-trip follow-up. And when students have little context for international and intercultural experiences, not only is learning compromised, but it also further enhances the 
possibility of exploiting international partners (Howard, 2011; Illich, 1993; McMillan \& Stanton, 2014).

\section{Short-term international service-learning course}

As a way to integrate short-term international education within the academic curriculum a growing number of faculty members are leading short-term international service-learning courses, often in winter or summer terms. At Providence College these courses adopt a variety of formats ranging from community-based research done by faculty and students, as seen in a long-term collaboration between an engineering faculty member and local communities in Ghana to develop micro-flush toilets (Mecca et al., 2013), or a more recent course in South Africa exploring "social infrastructures" which focuses on helping students learn how to engage in communities by studying these issues alongside local college students and community members from Cape Town. These courses can be more intensive and for longer durations allowing for deeper international partnerships and a more immersive experience. Because they are credit-bearing, they can focus more intentionally on student learning. This model, however, allows little time for pre- and postreflection/engagement given the nature of the course as trip. As a result post-trip reflection is often limited to individual papers or perhaps a campus presentation with little time for group reflection or follow-up. It is also not likely that local engagement can be connected with an international course.

\section{Course embedded spring break international service trip}

Course embedded spring break international trips respond to several of the critiques mentioned above, as spring break service trips take place approximately mid-semester allowing for more structured pre-and post-trip preparation and reflection. The first global service-learning course at Providence College was offered using this model in 2010. Community Engagement in Latin America was a course model which enabled students to prepare for the immersion with readings, guest speakers, and local immersion; and the curriculum post-trip was developed collaboratively based on the experiences during spring break. Thus, students have time to more deliberately prepare with several weeks of classes together and then build upon international service with follow-up reflection during the semester, along with local community engagement. Subsequent courses using this model at Providence College have studied "coffee culture," "food security," and "border crossing" in Latin America. A challenge to the alternative spring break model is the international experience is timebound to one week abroad and with travel days this can mean as little as five days spent in-country.

\section{Curricular embedded pre- or post-course international service trip}

Finally, international immersion can take place prior to a semester-long course or immediately following the course. When done prior to the trip this allows for longer-time periods abroad and for the international experience to frame student-learning with deep reflection. There is also opportunity for follow-up work with international partners, along with building connections through local immersion during the semester. The challenge, of course, is students have less time to prepare for their time abroad. This is the model used in the Voices Across Borders: Storytellers of Our Communities course described in detail below. Conversely, the international immersion can take place after the semester course, during winter or summer, allowing students to be well prepared for the international service but with little time for follow-up reflection and action. 


\section{The Global Service-Learning (GSL) program at Providence College}

In collaboration with the Feinstein Institute for Public Service, Global Studies launched a global service-learning program beginning in spring 2014 offering several international community engaged courses each year (with winter, spring break, and summer trips abroad). Global service-learning reflects how the broader Global Studies major at Providence College approaches learning and global engagement. Global Studies, launched in 2005 as a program and established as department in 2013, is an interdisciplinary major aiming to prepare the next generation to engage responsibly with our increasingly interconnected world (Alonso García \& Longo, 2013). This is accomplished through an interdisciplinary curriculum that constantly expects learners to bring a great sensitivity to local cultures and identities as they develop their capacity to act as global problem-solvers and engaged citizens.

From the beginning Global Studies has uniquely focused on understanding the intersection of the local and international through experiential learning taking place in the Providence community and around the world. As a result the practice of the pedagogy of service-learning has been integral from the establishment of the program. The signature aspect of this model is preparation for, and reflection upon, global service-learning which transcends the classroom boundaries and builds a deeper sense of global responsibility.

To support this effort a four-credit course, GST 371 Topics in Global Service Learning, was collaboratively developed among Global Studies faculty, staff, students, and community partners, shifting spring break service programs from a co-curricular to a course embedded model. Past trips to Ecuador, Nicaragua, Mexico, and South Africa have examined a diverse array of themes such as community literacy, storytelling, youth development, global border crossing, social infrastructure, peace and justice, coffee cultures and food security.

The Global Service-Learning Program represents a conceptual shift toward what has been termed an "ecology of education" (Cremin, 1976), recognizing that education takes place in multiple, interconnected settings. A principle of ecology is that each living organism has an ongoing and continual relationship with every other element that makes up its environment. Thus, in our ecosystem there is interdependence and interconnection between the many parts of the whole environment. Applying the principles of ecology to education begins with the recognition that not only do many institutions provide for educative growth but also that the different places, people, events, and institutions that provide learning opportunities are related to one another in a potential learning web (Longo, 2007). Practicing the concept of ecology of education in short-term international service-learning asks us to shift to "thinking globally" and then recognize the interconnections that short-term experiences abroad can have with longer-term engagement in home communities.

Hovey \& Weinberg (2009) note that this way of thinking — the ecology of education- "can be used as a guiding concept" for "educational activities beyond the borders of our local communities and nation" (p. 39). Citing a series of programs, including the School for International Training (SIT) which is a leading study abroad program which connects the international with the civic, they conclude that "much of the gain as global citizens may actually take place through the reentry 
process" (p. 43). They continue that this is where "students come back with the commitments and capacities to engage in public work across national and cultural differences in order to create a better world" (p. 46).

This global ecology can be seen most especially in a particular GSL curricular embedded project - Voices Across Borders - a global service-learning project facilitated in partnership with NGO Waves of Hope $^{1}$ whose work focuses on community education and empowerment in El Manzano, Nicaragua and, in collaboration with CityArts, a youth arts organization in Providence, and 360 High School, a new public high school in Providence. By using this project as a case study we hope to unearth civic practices which connect local and international engagement and, ultimately, support enabling short-term engagement to have a greater impact.

In Voices Across Borders, Providence College faculty and students critically interpret issues related to youth literacy and arts education across borders through a global service-learning course that has been developed collaboratively with community partners and sustained now for five years. Waves of Hope has been investing in strengthening local education, improving access to health services and infrastructure in the rural northern Nicaraguan community of El Manzano Uno since its founding in 2009. Providence College partnership with Waves of Hope was then established in 2012 in our desire to learn from the community development practices that the NGO implements and to support their education programming efforts.

In collaboration with Waves of Hope staff, we devised short-term service-learning trips to El Manzano Uno which have focused on community literacy, youth development, and storytelling. The trips occur prior to the start of the semester (the fourth model described above) and precede the academic work associated with the course on campus and in the Providence community. However, even though the course proceeds the trip, prior to departure students are still responsible for examining and discussing their attitudes on international community engagement and cultural immersion in the framework of Bennett's (2004) intercultural sensitivity, learning about the politics and education of Nicaragua (Belli, 2003; Walker \& Wade, 2011), and intensive planning of the workshops conducted abroad. It should be noted that with each trip, Providence College participants have worked collaboratively to facilitate workshops with youth from the local communities on topics such as "community traditions and cultural heritage", "gender and women's health" and "leadership toward mentorship." These workshops utilize the power of storytelling to explore identities, attempt to build reciprocal relationships, and reflect on community practices.

An essential aspect that makes this short-term experience have a greater impact is that participants in Voices Across Borders then further develop these themes when they return to Providence in collaboration with a local community partner. This collaboration began with workshops at Providence CityArts for Youth and has grown over the past two years to include workshops at 360 High School. CityArts provides free professional art-based education to

\footnotetext{
${ }^{1}$ Waves of Hope is a non-profit organization registered in Canada, whose founders were committed since its establishment to involve the local community of El Manzano and its leaders in devising projects that will contribute to better the lives of the families inhabiting the area through education, health care and infrastructure initiatives. Waves of Hope practices a model of leadership that engages community voices in the decision-making processes and the implementation and evaluation of the projects developed in collaboration with the local leaders.
} 
Providence youth in a fully developed community-based arts center that reflects, encourages, and promotes the rich diversity of Providence, while 360 High School is a newly developed public high school focused on participatory education. While both local partnerships are multi-faceted, the collaboration with Voices Across Borders has enabled cross-border programs in which students teach photography courses and lead storytelling seminars adapted from the workshops led in Nicaragua. Students also develop similar workshops with youth at CityArts and 360 High School around the themes mentioned above, gender and women's health, storytelling, identity, and language, with the products from these collaborations digitized and part of a final art exhibition which includes video, photography, podcast and writing projects from youth from Providence and El Manzano Uno. ${ }^{2}$

\section{Civic practices}

William Kilpatrick's observation that "an actual situation responsibly faced is the ideal unit of educative experience," (1936, p. 20) perfectly captures our experience with short-term global servicelearning with Voices Across Borders. In the echoes of John Dewey's writing on the importance of realworld experience and cross-cultural immersion, Kilpatrick notes that how we do our work is as important as what we are doing as education. Thus, we have worked hard to develop a set of civic practices which supports us in doing our work with integrity (Morton, 1995) and in ensuring that short-term experiences are facilitated responsibly.

As a result the Voices Across Borders project has served as a space for us to reflect on the civic practices that might enable a longer-term impact for global service-learning initiatives. Undergirding all of these practices is the belief that we need to connect local and international engagement. Thus, these practices guide our work in thinking and acting globally by engaging in mutual and reciprocal partnerships which deepens international education with local engagement and vice versa. Our experiences have helped us built several pillars to support global engagement across borders by: i) fostering storytelling across borders; ii) cultivating students as partners; iii) developing reciprocal community partnerships; and iv) creating public work, developing visual, auditory or performing public artifacts.

\section{Fostering storytelling across borders}

Storytelling is a powerful civic practice for global service-learning. Building on previous findings (Alonso García \& Longo, 2015), creating and sharing stories is an integral part of the human experience. Not only do stories offer us a source of inspiration, they also contain a potential for understanding the many ways in which we value and devalue ideas, trends, and actions. Stories are paradoxically unique and universal: they exist within us, they define us. Stories allow individuals to reflect on their personal trajectory, understand the complexities of life, and develop an awareness of the variety of voices involved in authentic narratives. Stories support communities in constructing identity and celebrating heritage as they portray values that define a communal idiosyncrasy.

Recognizing the power of storytelling, Marshall Ganz (2007) demonstrates how the art of leadership can utilize what he terms "public narrative" to illustrate one's values and ultimately mobilize others to solve public problems. He argues that a public narrative emerges from critical

2 See some of these products at www.voicesacrossborders.com. 
moments ("the experience of challenge, choice and outcome") which involves a story of self, a story of us, and a story of now. In our Voices Across Borders community engagement experiences, we have witnessed how storytelling is a civic practice for motivating learners to analyze issues concerning their communities, reflect on their own cultural heritage, and get inspired to create and envision future change. As one Providence College student (2016) explained: "I think storytelling is one of the most effective methods of communication and building relationships. When hearing someone's story, it is natural that you will connect with that individual in a personal and emotional way, a way that would be impossible without the vulnerability that comes with sharing stories. Storytelling requires trust and comfort; once this is built, the amount that you can learn from a personal narrative is immeasurable."

Storytelling has been at the heart of the global service-learning projects conducted in Nicaragua and locally at Providence CityArts. For instance, Providence College faculty and students have facilitated a number of workshops to capture stories and engage in dialogue about education equality and social justice with youth from El Manzano Uno and Providence South Side communities. Voices Across Borders has developed programs with Nicaraguan youth involved with Waves of Hope and with Providence CityArts and 360 High School intended to explore the different ways stories can be shared, create community among participants by sharing narratives, and discuss the potential of storytelling for crossing borders. One student reflected:

It is often difficult to hear the voices of not only marginalized groups of individuals, but also youth. Youth sometimes lack the essential trust and community aspects that are necessary for sharing stories, and for that reason they must be empowered. Creating a voice for youth is one of the most important parts of growth and development, and it allows them to learn about themselves and their communities.

In recent workshops, youth participants in Nicaragua and Providence worked on developing their stories, reflecting on the themes of family dynamics and literacy, community, dreams, and justice in the world. Storytelling projects begin with the story of self, where youth participants reflect on how they have come to be the person they are today and visually capture their journeys thus far in drawings or photographic forms. This imagery is displayed in public exhibitions, photo documentaries and photography books curated by Providence College students. Next, participants consider the story of my community where workshop facilitators conduct oral interviews and record youth about how their communities have helped shaped their identity and what is special about their communities. These interviews are later edited and crafted into podcasts that tell a larger audience the story of the communities portrayed, the legacy of elder members, and experiences of intergenerational dialogue. The culmination of the storytelling projects is the development of monologues that workshop participants develop in their native language, guided by Providence College facilitators, with questions such as: who you aspire to become, what challenges your community face, how we address these challenges as a community and, what mark you want to leave on your community? These monologues have been performed in public spaces such as schools and galleries, for a broader public, with products such as videos, photos, and documentary projects also developed by Providence College students.

These kinds of workshops capitalize on the power of storytelling to explore personal identities and reflect on the legacy of community heritage as youth pursue their future endeavors. It is also 
challenging, given the power and privilege which comes with being situated in a private university in the Global North. With an awareness of the power imbalance, we attempt to use art in transnational contexts, creating space for voices and images to narrate the stories of the community. And in crafting the narratives, the intention is to make these stories public so that we can see the force and complexity of communities of people while combating the danger of the "single story" (Adichie, 2009). This approach enables participants to reflect upon the value of narratives, to learn about and practice reciprocal relationships, and to enhance student linguistic and intercultural competence.

\section{Cultivating students as partners}

A second civic practice involves re-imagining students as leaders, colleagues, and producers as opposed to passive consumers of their education. This approach gives students a real voice in decision-making rather than being recipients of the decisions of others. Even more than a practice for global service-learning, it represents a choice about the future of leadership in higher education. We can choose to reinforce the dominant way of knowing that tends to minimize-and too often ignore-the capacities and experiences of our students, the very people we most want to engage (but this also applies to community partners). Or we can take student empowerment seriously as part of the larger civic mission of higher education.

An essential practice for short-term service-trips needs to be empowering student leaders. While this is especially prescient for the co-curricular trips described above, it can also be central for curricular-based global service-learning. For instance, we have learned from another service-learning example, where the University of Massachusetts-Amherst has created a "professorless classroom" in which undergraduate students in the UMass Alliance for Community Transformation (UACT) program (who are alumni of the course) lead grassroots organizing projects during a spring course, Grassroots Community Organizing (Addes \& Keene, 2006). The student instructors participate in two courses to prepare to lead the course: Critical Pedagogy in the fall semester, and then Leadership and Activism runs simultaneously with the alternative spring break organizing course during the spring semester. Building upon the lessons from this model, the Global Service-Learning program has students and faculty collaborate on courses with international service-learning trips. Student trip leaders are selected by course instructors and typically have prior experience with their corresponding course or trip. In addition to four-course credits, students are paid a modest stipend to go towards the costs of their trip.

With all the Global Service-Learning courses, but especially Voices Across Borders, student leaders play a vital role in spreading awareness about the program across campus as well as recruiting a diverse group of talented and engaged students for the program. The application process is also quite participatory with trip leaders working alongside an instructor to conduct interviews and having an equal voice when it comes to participant selection. Trip leaders then support the program through pre-departure logistics, fundraising, and team building. They ensure that their peers fulfill their responsibilities by attending to the planning of meetings, getting organized in work teams and delivering the tasks assigned in a timely manner. They also engage in reflective practice based on each session's facilitation. Trip leaders are co-facilitators for group reflection sessions, before, during, and after the international experience, and serve as collaborators in the development of the syllabus, facilitation of the weekly classes, and evaluation of their peers. 
Since student leaders are alumni of the class (having taken the course the prior year), they play a unique role in the community engagement, guiding the planning and facilitation of the workshops in Nicaragua and Providence. The approach to the public narrative workshops that students develop prior to the service-learning in Nicaragua and in Providence is directed by ongoing conversations with community partners to ensure that workshop content is aligned with the youth programming expectations. Student leaders participate in these conversations, offering feedback based on previous experiences working with the community stakeholders, and acting as mentors for students in the class who are working in these communities for the first time. This type of work is challenging and relies on student leaders to stretch themselves acting as both mentors and connectors.

\section{Developing reciprocal community partnerships}

A strong focus on student leadership can sometimes tip the balance away from an emphasis on community voices. Doing partnership work with reciprocity and mutuality is challenging enough, but even more difficult when the scope is short-term engagement. With the best of intentions, short-term trips face the risk of becoming transactional, "a series of one-way transfers of goods" that meet immediate needs and then dissolve (Enos \& Morton, 2003).

To address these concerns, a third civic practice asserts that a successful community-campus partnership is enabled by linking campus and community in a reciprocal, common, longer-term purpose.

Eric Hartman puts reciprocity at the core of international partnerships when he defines what he terms "fair trade learning" as "global educational partnership exchange that prioritizes reciprocity in relationships through cooperative, cross-cultural participation in learning, service, and civil society efforts" (Hartman et al. 2012). With this as a goal, it has been essential to recognize Novella Keith's (2005) concern about the limitations of reciprocity within unequal relationships in service-learning, especially if the effort is framed as a goal between the server and served. She instead recommends that these collaborations focus on the importance of interdependence where the service-learning relationship is "a partnership" (p. 16).

This partnership orientation emerges in the workshops in Voices Across Borders, which are driven by a shared commitment to develop youth programming that supports the academic and social growth of all participants. The workshops involve conversations and planning with partner organizations, collaborative outcomes which are co-created through mutuality and respect. One student explains:

The relationships we made that week were not one sided or one community trying to "help" the other, it was mutual. The Nicaraguan community taught us so much and also gained so much from us as well. I never once felt like we the Providence College students were the teachers, the whole time I felt like two communities were coming together.

Along these lines, Dostilio et al. (2012) examine in depth the concept of reciprocity in community engagement, and discuss several approaches, including not only exchange and influence oriented reciprocity, but also generativity oriented reciprocity. It is this last area, generativity, where we understand that our global service-learning projects can have more lasting impact. With generativity 
participants co-create knowledge, embrace individual transformation and redefinition of the self through the partnership, and change as the partnership evolve (Dostilio et al. 2012).

Generative reciprocity can be even more challenging when working across borders with both local and international partners. That is why our experiences working with CityArts, 360 High School, and Waves of Hope for the past five years have shown us the importance of setting realistic expectations and making decisions that account for the variety of voices involved in the projects. As part of our collaborative work, we constantly reassess our role in supporting our partners' efforts in carrying out projects deemed of priority by community leaders for the growth and well-being of the community members, so we strive to practice authentic, reciprocal, and sustainable collaborations. The primary example of reciprocity in practice involves how the workshops have developed over the years, always being requested by the community partners and then developed, implemented and assessed through a collaborative process.

\section{Creating public work: Visual, auditory or performing artifacts}

Reciprocal partnerships are engaged in producing creative work that "connects and migrates across different domains of knowledge" as recognized by Ellison \& Eatman's (2008, p. 9) research on publicly engaged scholarship. As such, it most often cannot be assessed by means of traditional instruments, i.e. conventional methods of assessment which usually involve completion of a written document such as a quiz, exam, or paper. We have learned to devise writing projects to assess global service-learning that include free flowing journal writing and visual representations throughout the project, reflective writing assignments on topics derived from the community immersion and engagement experience that deepen students understanding of the socio-economic and political contexts, and final reports to share with all the constituencies involved describing the objectives, development and outcomes of the project.

These help us understand the importance of the civic practice of aiming to co-create sustainable, public products, what Harry Boyte (2011) terms "public work", as the outcome of global partnerships. Boyte defines public work as "efforts by a mix of people who create things, material of symbolic, of lasting civic value" (p. 94). This kind of effort shifts global service-learning partnerships from a disempowering servant-client relationship towards a reciprocal relationship where all participants are co-producers. A "thick" model of reciprocity is practiced, "one that emphasizes shared voice and power and insists upon collaborative knowledge construction and joint ownership of work processes and products” (Jameson et al 2011, p. 263).

Public work produces artifacts which are varied such as photography, voice interviews and stories in the form of podcasts and videos, and other public art which is then made public and visible. Providence College students in the Voices Across Borders seminar also "curate" their own learning using an eportfolio, developing a space where these stories can be shared on the web through a Weebly web page. This digital space is devoted to the Waves of Hope, CityArts, and 360 partnerships hosting the photos, videos, podcasts, reflections and documentaries from the servicelearning engagement across borders including the Nicaragua workshop sessions and camps and workshops facilitated at CityArts and 360 High School. The site continues to be built by participants as the project unfolds while this effort evolves overtime as a reflection of the commitment to sustainable products and longer-term partnerships. Our purpose is to promote sustainable products 
in connection to art education, reading and writing literacy, and storytelling in order to offer a public forum for stories to unfold and to support youth communities across borders to embrace their voices with pride and confidence.

\section{Challenges and possibilities}

While we recognize the value of these civic practices the most daunting challenge for shortterm global service-learning is the inevitable constraints of students making longer-term commitments to the partnerships, namely the "problem of time." This recalls the story of university administrator Herman Blake attempting to set up internships for some of his college students from Santa Cruz at the Highlander Folk School, the educational center in Tennessee best known for its work in the civil rights movement (Longo, 2007). Blake thought a partnership with Highlander would be an ideal learning experience for his students, but the director of Highlander at the time, Myles Horton, responded by demanding "that they stay with us for two years" (as cited in Wallace, 2000, p. 133). This is a long way from the commitment we ask in our global-service-learning courses.

And even as yearlong commitment to study abroad has decreased, a body of research seems to confirm the truism that "more is better" when it comes to international immersion. "Clearly the greatest gains across all outcome categories are made by full-year students," one study found, concluding "the age-old premise that 'more is better' holds true when it comes to the duration of a study abroad experience" (Dwyer, 2004, pp. 161-62). Likewise, research has found, for example, significant correlations between program duration and increased oral proficiency in the target language along with intercultural learning gains (Vande Berg et al., 2009).

This data illustrates the challenges with lack of language competency and the possibility for cultural exchange without speaking the target language in short-term programs. Entering a community with an understanding of the native language and cultures facilitates more authentic interactions between participants and community members while fostering greater cultural humility and respect for the linguistic diversity of our world (Burleson, 2015; Fantini \& Tirmizi 2006; Wells, 2013). Our responsibility is to help global service-learners participate in the host culture with sensitivity, mindful of the sociocultural boundaries many face as non-native speakers which requires a willingness to be vulnerable while engaging in collaborations with the community in their own language. As such, Voices Across Borders has a Spanish language requirement so most students have a level of Spanish fluency which is unique to global service-learning projects in Latin America. By so doing, we honor the linguistic and cultural heritage of the communities with whom we collaborate and foster more equitable partnerships. With language fluency student leadership in cross-cultural engagement creates a more vibrant global pedagogical framework and contributes to ensure the long-lasting impact of the intercultural experiences.

We also need to acknowledge that students are too often unprepared for short-term engagement abroad, bringing "good intentions" but, potentially, more harm than good. Former study abroad student, Talya Zemach-Bersin (2008) questions whether study abroad, and by extension, global service-learning, can educate students for global citizenship. She writes that international experiences by American college students "may inadvertently be a recipe for the perpetuation of global ignorance, misunderstanding, and prejudice." She concludes, "There is a vast 
discrepancy between the rhetoric of international education and the reality of what many students like myself experience while abroad."

Ivan Illich's (1993) provocative speech, "To Hell with Good Intentions," calls into question the very idea of global service-learning. Illich makes known his opposition to North American "dogooders" in Latin America and challenges the idea that the service by international volunteers is relevant or helpful to the communities they hope to serve. He concludes that international visitors are welcome as travelers or students, but not as volunteers, writing: "Come to look, come to climb our mountains, to enjoy our flowers. Come to study. But do not come to help" (Illich, 1993, p. 460). There has also been a growing number of articles in the popular media about the harm of shortterm "voluntourism" on local communities (Biddle, 2014; Hartman, 2014; Kushner, 2016).

Along these lines there has been a dearth of research that genuinely addresses these disparities by giving voice and power to the "unheard voices" (Ogden, 2008; Stoecker \& Tryon, 2009; Stoecker, 2016) of communities themselves-our local and international partners. This, of course, is an acknowledged limitation in our case study which is tilted, like so much of the service-learning and international education fields, by a "view from the veranda" (Ogden, 2008) relying on the positionality and reflections of the university partners. Overcoming this power imbalance and making the construction of knowledge genuine co-creations needs to be a priority moving forward for all of us who care about reciprocal and sustainable global engagement.

And yet, these challenges don't mean we can't do "more with less" when short-term global service-learning is developed in ways that attempt to mitigate these challenges by incorporating the civic practices described above. As the Study Abroad for Global Engagement (SAGE) research team from the University of Minnesota (Paige \& Fry., 2010) found: "What really counts is not how long you stay or where you go, but the quality of the program and the nature of deep cultural and learning experiences provided." Paige and his colleagues conclude, "If done in the right way, shortterm study abroad can have impact" (p. 7). Our experiments with local-global engagement with Voices Across Borders illustrates that thinking more comprehensively about what it means to do the "global" in global service-learning is an important first step. When done well the local can be connected with the international. The practices we set forth then provide much-needed tools for making short-term global service-learning programs have greater impact.

The goal of greater impact requires a humble approach to global service-learning, making explicit what is possible and not feasible in a short-term. Janice McMillan and Timothy Stanton (2014) offer a roadmap with their important framing of global service-learning as very explicitly not about service, rather it is about collaborative learning. Shifting the frame McMillan \& Stanton write, "Through an intentional process where we seek to understand service, we can begin to assist our students - and ourselves - to be more open about and critical of our own assumptions and worldviews" (p. 66). The service-learning trips in the Voices Across Borders project have allowed us to interact with rural Nicaraguan and urban Providence youth, to learn by immersion about the life and heritage of the local community, and to practice a global service-learning model that nurtures respect, fosters civic responsibility and supports learning in partnership. With an orientation focused on learning we can extend our work beyond the short-term global by linking learning at the international and the local levels. And using the civic practices described above, it seems more likely 
that we can create quality programs and relationships to have a longer impact even in short-term global service-learning.

\section{REFERENCES}

Adichie, C. (2009). The danger of a single story. TedGlobal. Retrieved at https://www.ted.com/talks/chimamanda_adichie_the_danger_of_a_single_story?language=en

Addes, D. \& Keene, A. (2006). "Grassroots community development at UMass Amherst: The professorless classroom." In E. Zlotkowski, N. Longo, \& J. Williams (Eds.), Students as colleagues: Expanding the circle of service-learning leadership (pp. 227-240). Providence, RI: Campus Compact.

Alonso García, N. and Longo, N. (2013). Going global: Re-framing service-learning in an interconnected world. Journal of higher education outreach and engagement, 17(2), 111-136.

Alonso García, N. and Longo, N. (2015). Community voices: Integrating local and international partnerships through storytelling. Partnerships: A Journal of Service-Learning and Civic Engagement, 6(2), Summer, 1-18.

Bennett, M. (2004). "Becoming intercultural competent." In Wurzel, J. (Ed.). Toward multiculturalism: A reader in multicultural education (pp. 62-77). Newton, MA: Intercultural Resource Corporation.

Belli, G. (2003). El país bajo mi piel. Memorias de amor y guerra. The country under my skin. A memoir of love and war. Great Britain: Clays LTD.

Biddle, P. (2014). The problem with little white girls, boys and voluntourism. Huffington Post. Retrieved at http://www.huffingtonpost.com/pippa-biddle/little-white-girls-voluntourism_b_4834574.html?\&

Boyte, H. (2011). Public work and the politics of the commons. The Good Society. 20(1), 84-101.

Bringle, R., Hatcher, J., \& Jones, S. (Eds.). (2011). International service learning: Conceptual frameworks and research. Sterling, VA: Styles Press.

Burleson, K. (2015). A guidebook for the development of cultural mindedness. Retrieved at http://www.interculturalservice.org/online-guidebook/

Cremin, L. (1976). Public education. New York: Basic Books.

Donnelly-Smith, L. (2009). Global learning through short-term study abroad. Peer Review, Association of American Colleges and Universities. Retrieved at https://www.aacu.org/peerreview/2009/fall/donnelly-smith

Dostilio, L. D., Brackmann, S. M., Edwards, K. E., Harrison, B., Kliewer, B. W., \& Clayton, P. H. (2012). Reciprocity: Saying what we mean and meaning what we say. Michigan Journal of Community Service Learning, 19(1), 17-32.

Dwyer, M. (2004). More is better: The impact of study abroad duration. Frontiers: The Interdisciplinary Journal of Study Abroad, 10 (Fall), 151-163.

Ellison, J. and Eatman, T. K. (2008). Scholarship in public: Knowledge creation and tenure policy in the engaged university. Imagining America: Artists and Scholars in Public Life Tenure Team Initiative on Public Scholarship. Retrieved at http://imaginingamerica.org/wpcontent/uploads/2015/07/ScholarshipinPublicKnowledge.pdf

Engle, J. \& Engle, L. (2012). Beyond immersion: The American University Center of Provence experiment in holistic intervention. In Vande Berg, M., Paige, R. M., \& Lou, K. H. (Eds.). Student learning abroad: What our students are learning, what they're not, and what we can do about it (pp. 284-287). Sterling, VA: Stylus Press.

Enos, S., \& Morton, K. (2003). "Developing a theory and practice of campus-community partnerships." In B. Jacoby (Ed.), Building partnerships for service-learning (pp. 20-41). San Francisco: JosseyBass.

Fantini, S. \& Tirmizi, N. M. (2006). Exploring and assessing intercultural competence. World Learning Publications. Paper 1. Retrieved at http://digitalcollections.sit.edu/cgi/viewcontent.cgi?article=1001\&context=worldlearning_publicatio ns 
Ganz, M. (2007). What is public narrative? Harvard, MA: Kennedy School. Retrieved at https://commorg.wisc.edu/syllabi/ganz/WhatisPublicNarrative5.19.08.htm

Hartman, E. (2014). Why UNICEF and Save the Children are against your short-term service in orphanages. Retrieved at http://globalsl.org/why-unicef-and-save-the-children-are-against-youcaring-for-orphans/

Hartman, E. \& Kiley, R. (2014). Pushing boundaries: Introduction to global service-learning special issue. Michigan Journal of Community Service-Learning, 21(1), 55-63.

Hartman, E., Paris, C, and Blache-Cohen, B (2012) Tourism and Transparency: Navigating ethical risks in volunteerism with fair trade learning. Africa Insight 42(2), 157-168.

Healey, M., Flint, A. \& \& Harrington, K. (2014) Engagement through partnership: Students as partners in learning and teaching in higher education. Retrieved at https://www.heacademy.ac.uk/sites/default/files/resources/engagement_through_partnership.pdf

Holland, Barbara A. (2005). "Reflections on community-campus partnerships: What has been learned? What are the next challenges?" In P. A. Pasque, R. E. Smerek, B. Dwyer, N. Bowman, and B. L. Mallory (Eds.) Higher education collaboratives for community engagement and improvement (pp. 10-17). Ann Arbor, MI: The national forum on higher education for the public good.

Hovey, R. and Weinberg, A. (2009). "Global learning and the making of citizen diplomats." In R. Lewin (Ed.). The handbook of practice and research in study abroad (pp. 33-48). New York: Routledge.

Howard, J. (2011). Service-learning course design workbook. Ann Arbor: Michigan University Press.

IIE: Institute of International Education \& Bureau of Educational and Cultural Affairs U.S. Department of State (2015). Open Doors 2015 Report on International Educational Exchange. Retrieved at http://www.iie.org/Research-and-Publications/Open-Doors\#.VzsUmWZ4zEJ

Illich, I. (1993). "To hell with good intentions." In B. R. Barber \& R. M. Battistoni (Eds.). Education for democracy: Citizenship, community, service: A sourcebook for students and teachers (pp. 456-460). Dubuque, IA: Kendall Hunt Publishing.

Jameson, J. K., Clayton, P. H., \& Jaeger, A. J. (2011). Community engaged scholarship as mutually transformative partnerships. In L. M. Harter, J. Hamel-Lambert, \& J. L. Millesen (Eds.) Participatory partnerships for social action and research (p. 263). Dubuque, IA: Kendall Hunt Press.

Keith, N. (2005). Community service learning in the face of globalization: Rethinking theory and practice. Michigan Journal of Community Service Learning 11, 5-24.

Kilpatrick, W. (1936). Preface. Youth serves the community. New York: D. Appleton-Century Company.

Kushner, J. (2016). The voluntourist's dilemma. NYTimes Magazine. Retrieved at http://www.nytimes.com/2016/03/22/magazine/the-voluntourists-dilemma.html

Longo, N. (2007). Why community matters: Connecting education with civic life. Albany, NY: SUNY Press.

McMillan, J. \& Stanton, T. (2014). Learning service in international contexts: Partnership-based servicelearning and research in Cape Town, South Africa. Michigan Journal of Community ServiceLearning, 21(1), 64-78.

Mecca, S., Davis, H., \& Davis, A., (2013). Application of GSAP Microflush toilets: a sustainable development approach to rural and peri-urban sanitation. ECOSUD 2013, WIT, Bucharest.

Odgen, A. (2008). The view from the veranda: Understanding today's colonial student. Frontiers: The Interdisciplinary Journal of Study Abroad, 15, 35-55.

Paige, R. M., \& Fry, G. W. (2010). Beyond immediate impact: Study abroad for global engagement (SAGE). https://www.calstate.edu/engage/documents/study-abroad-for-global-engagement.pdf

Reilly, D., \& Senders, S. (2009). Becoming the change we want to see: Critical study abroad for a tumultuous world. Frontiers: The Interdisciplinary Journal of Study Abroad, 18 (Fall), 241-267.

Sandy, M. \& Holland, B. A. (2006). Different Worlds and Common Ground: Community Partner Perspectives on Campus-Community Partnerships. Michigan Journal of Community Service Learning, 13(1), 30-43.

Stoecker, R. \& Tryon, E. (Eds.). 2009. The unheard voices: Community organizations and service learning. Philadelphia: Temple University Press. 
Stoecker, R. (2016). Liberating service learning and the rest of higher education civic engagement. Philadelphia: Temple University Press.

Vande Berg, M., Connor-Linton, J., \& Paige, R. M. (2009). The Georgetown Consortium Project: Interventions for student learning abroad. Frontiers: The Interdisciplinary Journal of Study Abroad, 18, 1-75. Retrieved at http://studyabroad.isp.msu.edu/research/Research-VandeBerg-Georgetown.pdf

Vande Berg, M., Paige, R. M., \& Lou, K. H. (2012). Student learning abroad: What our students are learning, what they're not, and what we can do about it. Sterling, VA: Styles Press.

Vande Berg, M., Paige, R. M., \& Lou, K. H. (2012). "Student learning abroad. Paradigms and assumptions." In M. Vande Berg, R. M. Paige, \& K. H. Lou (Eds.), Student learning abroad: What our students are learning, what they're not, and what we can do about it (pp. 3-28). Sterling, VA: Styles Press.

Walker, T. and Wade, S. (2011) Nicaragua: Living in the shadow of the eagle. Boulder, CO: Westview Press.

Wallace, J. (2000). The problem of time: Enabling students to make long-term commitments to community-based learning. Michigan Journal of Community Service-Learning, 7(1), 133-142.

Wells, S. (2013). Rethinking service. The Cresset, 26(4), 6-14. Retrieved at http://the cresset.org/2013/Easter/Wells_E2013.html

Zemach-Bersin, T. (2008). American students abroad can't be global citizens. Chronicle of Higher Education, 54(26), p. A34. 